\title{
Earthworm species and density in semi-natural grasslands on rice paddy levees in Japanese satoyama
}

\author{
Keiko Kishimoto-Yamada ${ }^{\ddagger}$, Yukio Minamiya§ \\ ‡ Sado Island Center for Ecological Sustainability, Niigata University, 1101-1 Niibo-katagami, Sado, Niigata 952-0103, Japan \\ $\S$ Tochigi Prefectural Museum, 2-2 Mutsumi-cho, Utsunomiya, Tochigi 320-0865, Japan
}

\section{Corresponding author: Keiko Kishimoto-Yamada (kky_kei@yahoo.co.jp)}

Academic editor: Samuel James

Received: 15 Jul 2020 | Accepted: 19 Sep 2020 | Published: 29 Sep 2020

Citation: Kishimoto-Yamada K, Minamiya Y (2020) Earthworm species and density in semi-natural grasslands on rice paddy levees in Japanese satoyama. Biodiversity Data Journal 8: e56531.

\begin{abstract}
Earthworms contribute to the sustainability of food webs in the semi-natural grasslands of levees at paddy margins, which are typical components of satoyama, the traditional agricultural landscapes of Japan. Thus far, few studies have focused on earthworm fauna of paddy levees in satoyama. In this study, we investigated earthworm fauna and regional and monthly changes in earthworm density. We found at least 11 species of earthworms living within levees on Sado Island, central Japan. Two endogeic species, Amynthas corticis (Megascolecidae) and Eisenia japonica (Lumbricidae), were dominant in terms of number of adult individuals; these two species appeared in all study regions. We also estimated an average of $\sim 57.4$ individuals $/ \mathrm{m}^{2}$ for all stages of earthworms in levees, suggesting that rice paddy levees have relatively-high earthworm density. However, such tendencies differed depending on the region. In addition, monthly changes in density were observed in the topsoil of the levees. Our results imply that differences in earthworm assemblages amongst regions and months may influence the availability of food resources for various animals inhabiting satoyama.
\end{abstract}




\section{Keywords}

agricultural landscapes, Haplotaxida, Lumbricidae, Megascolecidae, Oligochaeta, preys, Sado Island

\section{Introduction}

Terrestrial earthworms are a high-potential food resource for secondary consumers (e.g. Lee 1985, Onrust and Piersma 2017). In satoyama, traditional agricultural landscapes of Japan, various types of animals [e.g. Japanese marten (Tatara and Doi 1994), moles (Yokohata 2005), birds (Minamiya et al. 2007, Nagata 2010, Endo and Nagata 2013), frogs (Hirai and Matsui 2000, Hirai and Matsui 2001) and carabid beetles (Okuzaki et al. 2010)] feed on earthworms. Thus, earthworms contribute to the sustainability of food webs in satoyama.

The levees of rice paddies, located at paddy margins and separating paddies from secondary forests, are typical components of satoyama. They are constructed and maintained to retain water in the paddies and to allow the passage of people and transportation of tools (Matsumura et al. 2014). Farmers generally maintain levee grasslands by periodic mowing or herbicide application. As large semi-natural grasslands have been converted to other land uses in Japanese satoyama, grasslands on rice paddy levees have recently been re-discovered as important refuges for grassland species of plants and animals. For example, previous studies demonstrated that traditional management practices for levee grasslands maintain high diversities of herbivore and plant species, including rare plant species (Uematsu and Ushimaru 2013, Uchida and Ushimaru 2014, Ohara and Ushimaru 2015). However, most studies of biodiversity in levee grasslands have focused on plant species; few have examinedthe soil fauna of paddy levees.

On Sado Island, central Japan, typical satoyama landscapes occur throughout the island. In addition, a re-introduction programme for the once-extinct Asian crested ibis, Nipponia nippon, has been underway on the Island since 2003 (Nagata and Yamagishi 2016). This bird species is listed as Endangered on the IUCN Red List 2018. Since re-introduction, the wild population of crested ibis has been steadily increasing; the recent population estimate is 368 wild individuals in 2018 (Bansho 2019). According to a recent study, wild crested ibis feed on earthworms on the levees of rice paddy margins, especially in the summer (Endo and Nagata 2013). However, the species composition and density of earthworms within levee grasslands on the island have not been examined. Basic information regarding earthworm fauna in semi-natural grasslands of rice paddy levees is necessary for efforts, such as the development of habitat management strategies and maintenance of viable crested ibis populations, as well as the conservation of foraging habitats of various animals living in satoyama. Therefore, the objective of the present study was to examine earthworm fauna, as well as regional and monthly changes in earthworm density on Sado Island. 


\section{Materials and methods}

\section{Study site}

This study was conducted on Sado Island, located in the Sea of Japan, approximately 40 $\mathrm{km}$ off the coast of Niigata Prefecture $\left(138^{\circ} \mathrm{E}, 38^{\circ} \mathrm{N}\right.$; Fig. 1). The Island has an area of $855.25 \mathrm{~km}^{2}$; it consists of two mountainous areas (Osado and Kosado) separated by the Kuninaka Plain. Rice fields cover almost the entire Kuninaka Plain. In Osado and Kosado, rural communities with rice fields are dotted along the mountains and coastline.

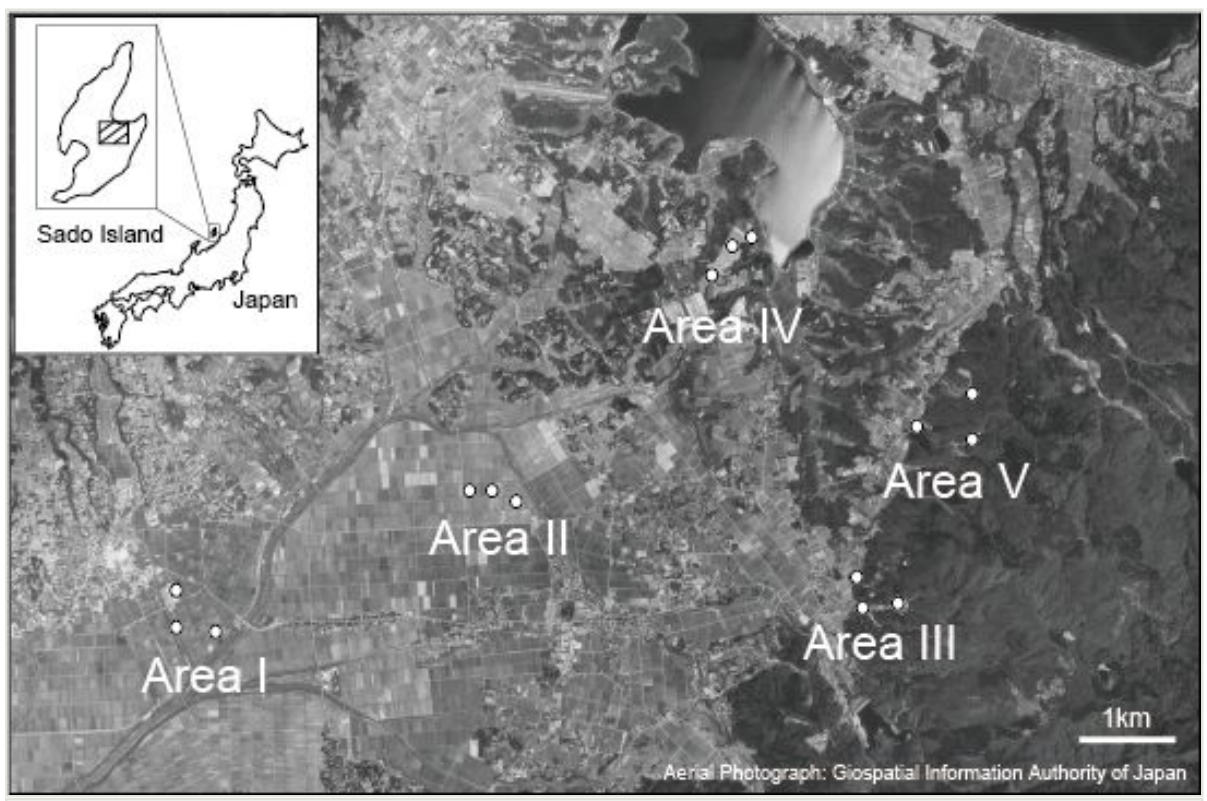

Figure 1. doi

Satellite image of the study site.

Five study regions on the Kuninaka Plain and in Kosado were selected (Fig. 1). These regions had different surrounding landscapes and farmland consolidation conditions. Areas I and II were surrounded by cultivated lands, while Areas III-V were surrounded by forests (Fig. 1, Table 1). In this study, farmland consolidation was considered to mean that the soil of the levee had been replaced once. More than 10 (13-37) years had passed since the completion of paddy consolidation in Areas II, IV and V (Table 1). In each region, three rice paddies, separated by at least $200 \mathrm{~m}$, were selected. The areas of the study paddies were $399-4,983 \mathrm{~m}^{2}$ (Table 1). In the studied paddies, farmers managed grasses on the levees by mowing two to five times per year and no herbicide was used. After mowing, litter was usually left on the levees; however, some farmers swept the litter away. Various grass species were found on the levees, such as Equisetum arvense, several Rumex and Trifolium species, Zoysia japonica and several other Poaceae and Polygonaceae species. 
Table 1.

Detailed characterisations for each study paddy and region. See Suppl. material 1 for the methods for the measurements of landscape conditions and soil properties.

\begin{tabular}{|c|c|c|c|c|c|c|c|c|c|c|}
\hline \multirow[t]{2}{*}{$\begin{array}{l}\text { Study } \\
\text { Region }\end{array}$} & \multirow[t]{2}{*}{ Paddy } & \multirow[t]{2}{*}{$\begin{array}{l}\text { Area of } \\
\text { paddy } \\
\left(\mathrm{m}^{2}\right)\end{array}$} & \multirow[t]{2}{*}{$\begin{array}{l}\text { Farmland } \\
\text { consolidation }\end{array}$} & \multicolumn{3}{|c|}{$\begin{array}{l}\text { Mean values of the percentages of } \\
\text { each land-cover type (\%) within a } \\
100-m \text { radius }\end{array}$} & \multicolumn{4}{|c|}{ Soil properties } \\
\hline & & & & $\begin{array}{l}\text { Cultivated } \\
\text { land }\end{array}$ & $\begin{array}{l}\text { Deciduous } \\
\text { broad- } \\
\text { leaved } \\
\text { forests }\end{array}$ & $\begin{array}{l}\text { Planted } \\
\text { forests }\end{array}$ & $\begin{array}{l}\mathrm{pH} \\
\left(\mathrm{H}_{2} \mathrm{O}\right)\end{array}$ & $\begin{array}{l}\text { Carbon } \\
\%\end{array}$ & $\begin{array}{l}\text { Nitrogen } \\
\%\end{array}$ & $\begin{array}{l}\mathrm{CN} \\
\text { ratios }\end{array}$ \\
\hline \multirow[t]{3}{*}{ I } & 1 & 1,023 & & 100.0 & 0.0 & 0.0 & 5.4 & 3.62 & 0.33 & 10.87 \\
\hline & 2 & 613 & none & 80.2 & 0.0 & 0.0 & 5.4 & 3.13 & 0.3 & 10.43 \\
\hline & 3 & 1,023 & & 100.0 & 0.0 & 0.0 & 5.5 & 4.09 & 0.4 & 10.26 \\
\hline \multirow[t]{3}{*}{ II } & 1 & 3,095 & & 100.0 & 0.0 & 0.0 & 5.5 & 2.59 & 0.24 & 10.67 \\
\hline & 2 & 3,855 & done & 100.0 & 0.0 & 0.0 & 5.7 & 2.68 & 0.26 & 10.14 \\
\hline & 3 & 4,983 & & 100.0 & 0.0 & 0.0 & 5.6 & 4.64 & 0.43 & 10.77 \\
\hline \multirow[t]{3}{*}{ III } & 1 & 762 & & 39.9 & 4.6 & 55.7 & 5.3 & 3.01 & 0.26 & 11.49 \\
\hline & 2 & 968 & none & 54.7 & 4.5 & 39.6 & 5.5 & 3.08 & 0.28 & 10.83 \\
\hline & 3 & 2,980 & & 66.9 & 0.0 & 32.7 & 5.5 & 5.19 & 0.41 & 12.6 \\
\hline \multirow[t]{3}{*}{ IV } & 1 & 2,848 & & 63.9 & 18.7 & 0.0 & 4.9 & 3.26 & 0.25 & 13.3 \\
\hline & 2 & 2,537 & done & 81.9 & 0.0 & 18.3 & 5.3 & 4.15 & 0.33 & 12.45 \\
\hline & 3 & 1,047 & & 61.5 & 25.5 & 0.0 & 5.3 & 3.18 & 0.24 & 13.51 \\
\hline \multirow[t]{3}{*}{ V } & 1 & 399 & & 39.0 & 16.6 & 19.7 & 5.2 & 2.81 & 0.22 & 12.74 \\
\hline & 2 & 847 & done & 25.6 & 74.8 & 0.0 & 5.5 & 2.17 & 0.22 & 10.02 \\
\hline & 3 & 469 & & 23.8 & 58.9 & 15.6 & 5.2 & 3.15 & 0.29 & 10.79 \\
\hline
\end{tabular}

\section{Earthworm sampling}

Sampling was conducted monthly from June to September 2017, which is the irrigation season. On Sado Island, earthworms were frequently fed by the wild crested ibis on paddy levees during this period (Endo and Nagata 2013) and a previous study revealed that earthworm abundances decreased by half and several species disappeared as of autumn (Harada and Yoshimura 2015). Three points on two or three levees surrounding each rice paddy were selected. At each point, a soil monolith $(25 \times 50 \mathrm{~cm}, 10 \mathrm{~cm}$ deep) was taken. Earthworms found in each monolith were hand sorted and all individuals with and without clitellum were counted in the field. The numbers of all individuals collected from all three 
points per rice paddy and per month were added. Only individuals with clitellum (i.e. adults) were taken to the laboratory, fixed with a $10 \%$ formaldehyde solution and preserved in $80 \%$ ethanol for species identification. The specimens are preserved at Tochigi Prefectural Museum (TPM).

\section{Data analysis}

To examine regional and monthly changes in earthworm densities, the densities were compared amongst study locations using the Kruskal-Wallis test and amongst months using the Friedman test, followed by post hoc analysis. Post hoc tests were conducted using the Nemenyi test in the PMCMR package. All analyses were performed using $R$ version 3.3.3 (R Core Team 2017).

\section{Data resources}

Species occurrence data of levee earthworms collected on Sado Island are listed in Suppl. material 2.

\section{Results}

The examination of individuals with clitella revealed the presence of eight Megascolecidae species, two Lumbricidae species and one Moniligastridae species at the levees (Table 2). Amynthas corticis and Eisenia japonica were the dominant species in terms of the number of adult individuals and both species appeared at all study regions (Table 2). These two species comprised approximately $85 \%$ of all adult individuals $(N=192)$; all other species only appeared infrequently (Table 2). Four species, A. aokii, A. micronarius, Metaphire agrestis and an unidentified species of Moniligastridae, appeared only at non-consolidated levees (Areas I and III).

Table 2.

Functional groups, monthly individual numbers and regional occurrences of adult earthworm species. En: Endogeic species, Ep: Epigeic species

\begin{tabular}{|c|c|c|c|c|c|c|c|c|c|c|}
\hline \multirow[t]{2}{*}{ Earthworm species } & \multirow[t]{2}{*}{ Functional groups } & \multicolumn{4}{|c|}{ Month } & \multicolumn{5}{|c|}{ Area } \\
\hline & & Jun & Jul & Aug & Sep & 1 & II & III & IV & $\mathrm{V}$ \\
\hline \multicolumn{11}{|l|}{ Megascolecidae } \\
\hline Amynthas corticis (Kinberg, 1867) & En & 39 & 8 & 6 & 24 & + & + & + & + & + \\
\hline Amynthas aokii (Ishizuka, 1999) & Ep & 0 & 1 & 0 & 0 & & & + & & \\
\hline Amynthas micronarius (Goto \& Hatai, 1898) & En & 2 & 2 & 0 & 0 & + & & + & & \\
\hline Amynthas tokioensis (Beddard, 1892) & Ep & 0 & 4 & 3 & 3 & + & + & + & & + \\
\hline
\end{tabular}




\begin{tabular}{|c|c|c|c|c|c|c|c|c|c|c|}
\hline \multirow[t]{2}{*}{ Earthworm species } & \multirow[t]{2}{*}{ Functional groups } & \multicolumn{4}{|c|}{ Month } & \multicolumn{5}{|c|}{ Area } \\
\hline & & Jun & Jul & Aug & Sep & 1 & II & III & IV & V \\
\hline Amynthas vittatus (Goto \& Hatai, 1898) & Ep & 0 & 0 & 1 & 0 & & + & & & \\
\hline Metaphire acincta (Goto \& Hatai, 1899) & En & 2 & 1 & 0 & 0 & & + & + & & \\
\hline Metaphire agrestis (Goto \& Hatai, 1899) & Ep & 0 & 0 & 2 & 0 & & & + & & + \\
\hline Metaphire hilgendorfi (Michaelsen, 1892) & Ep & 0 & 1 & 0 & 2 & & + & & & + \\
\hline \multicolumn{11}{|l|}{ Lumbricidae } \\
\hline Aporrectodea trapezoides (Dugès, 1828) & En & 2 & 0 & 0 & 0 & + & & & & \\
\hline Eisenia japonica (Michaelsen, 1892) & En & 45 & 39 & 3 & 0 & + & + & + & + & + \\
\hline \multicolumn{11}{|l|}{ Moniligastridae } \\
\hline Moniligastridae sp. 1 & - & 0 & 1 & 1 & 0 & + & & + & & \\
\hline
\end{tabular}

The ten species identified in this study can be categorised into two functional groups (Uchida and Kaneko 2004, Ishizuka 2015): five epigeic and five endogeic species (Table 2). Endogeic species comprised approximately $91 \%$ of all adult individuals ( $N=190$, with the exception of the unidentified species of Moniligastridae).

During the study period, 1,292 individuals with and without clitella were collected. The mean density was $21.53(0-58)$ individuals $/ 0.375 \mathrm{~m}^{2}$. Amongst the five regions, densities tended to be different (Kruskal-Wallis chi-squared $=22.53, p<0.001$ ): they were high in the Areas I and II, compared to Areas III-V (Fig. 2).

In addition, the total numbers of individuals tended to be different (Friedman chi-squared = 29.98, $p<0.001$ ): they were low in July and August, compared to values observed in June and September (Fig. 3a). Adults (individuals with a clitella) comprised $7 \%$ of all individuals and they also tended to be different (Friedman chi-squared $=22.49, p<0.001$ ), with adult density peaking in June and then decreasing in August and September (Fig. 3b). The densities of non-adult individuals (no clitella) were different (Friedman chi-squared $=22.49$, $p<0.001$ ): they were low in July and August, then recovered in September to densities comparable with those observed in June (Fig. 3c).

\section{Discussion}

This study identified at least 11 species of earthworms living within levees on Sado Island. Previously, only seven species (Amynthas divergens, A. hupeiensis, Metaphire acincta, Aporrectodea caliginosa, E. japonica, Helodrilus hachiojii and Drawida hattamimizu) had been recorded at rice paddy levees in Japan (Blakemore et al. 2010, Kiritani 2010). Eight species, including an unidentified Moniligastridae species, were newly observed in this study. 


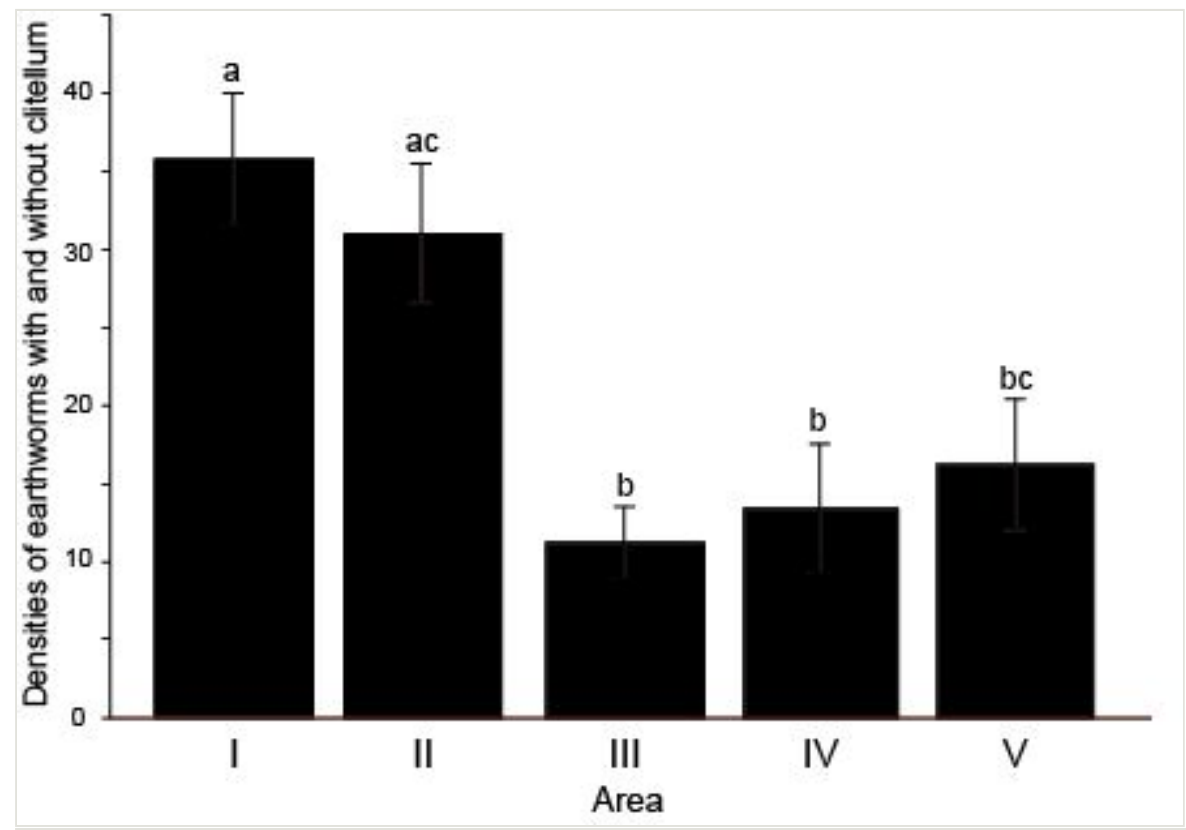

Figure 2. doi

Comparison of densities of earthworms with and without clitellum amongst study regions. Different letters indicate statistically-significant differences $(p<0.05)$.

Species diversity and evenness tended to be low at the rice paddy levees; only two species, A. corticis and E. japonica, were dominant. E. japonica is present in most ecosystems in Japan, including mountainous forests and grasslands (Hokkaido Development 1965). Kamihira (1973) reported that this species is found more frequently in grasslands than on forest floors; it also inhabits farmland and residential areas. $A$. corticis is often observed under decayed trees, in landfills and in parks, amongst other locations (Reynolds 1978). Farmers often walk upon, transport tools and periodically cut the grasses on rice paddy levees, particularly during the irrigation season. The two dominant earthworm species are presumably able to tolerate such habitats that experience relativelyintensive disturbances.

Levee grasslands may also be characterised by relatively-high earthworm densities. For example, previous comprehensive studies conducted in pastures and meadows in Hokkaido, northern Japan, recorded 35.5-200.4 individuals and 14.9-49.7 g/m ${ }^{2}$ biomass (Nakamura 1967, Kamihira 1968, Kamihira 1969). We observed averages of approximately 57.4 individuals $/ \mathrm{m}^{2}$ at the levees. The area of each paddy levee is generally very small. In addition, compared with other semi-natural grasslands, such as pastures and meadows, disturbance frequencies tend to be higher on levees, in terms of management by farmers (Ushimaru 2012). Nevertheless, the values obtained in this study were nearly within the ranges observed in pastures and meadows. Thus, we regard these semi-natural grasslands, which are typical components of satoyama landscapes, as important habitats for earthworms and their predators. 
a) Total individuals

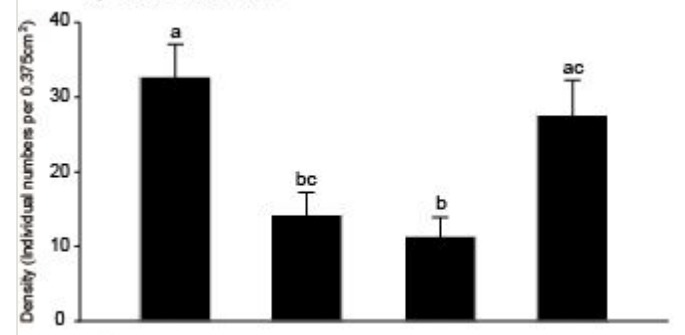

b) Adults

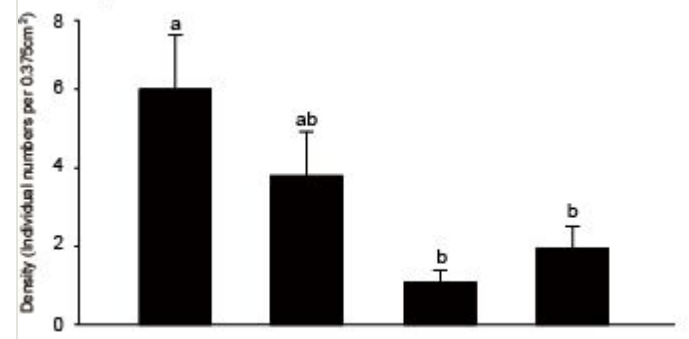

c) Non-adults (juveniles and sub-adults)

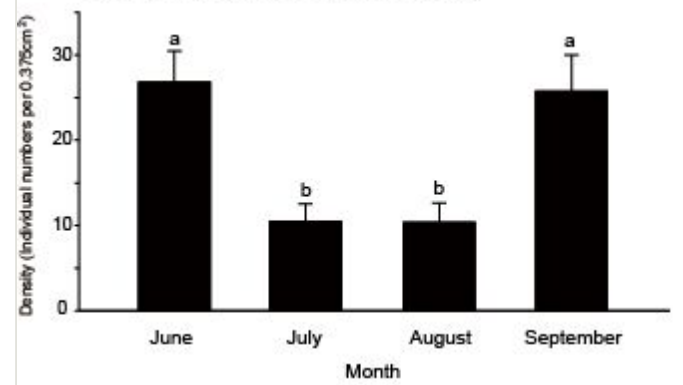

Figure 3. doi

Comparison of densities of a) total individuals, b) adults with clitellum and c) non-adults without clitellum amongst months. Different letters indicate statistically-significant differences $(p<0.01)$.

However, in the present study, we observed that earthworm densities differed amongst regions. In particular, densities were high at the levees without adjacent forest, compared to levees with adjacent forests. The situation of farmland consolidation and characteristics in soil properties (Soil $\mathrm{pH}, \mathrm{C}, \mathrm{N}$ and $\mathrm{C}: \mathrm{N}$ ratio) is unlikely to differ between these two types of levees (Table 1). Structures at margins between paddies and forests may reduce earthworm densities. Sklenicka et al. (2002) reported low porosity and infiltration rates in the soil in crop fields near forest edges and suggested that the phenomenon was caused by greater soil compaction, because the field boundaries are often used as corridors for agricultural machinery traffic. Alternatively, earthworm densities in levee grasslands with adjacent to forests may also be negatively affected by increased predation at the forest edge. For example, Andren (1992) found that the densities of corvid birds tended to increase in fragmented forests, as well as at the boundaries between forests and agricultural lands. Positive edge effects have also been documented for carabid beetles in 
various regions (e.g. Molnár et al. 2001, Magura 2002), although the effects differ amongst seasons (Ohwaki et al. 2015). In addition, the number of frog egg masses in paddies has been positively correlated with high proportions of surrounding forests within a $1000-\mathrm{m}$ radius on Sado Island (Uruma et al. 2012). These animals often feed on earthworms; therefore, high predation pressure at forest edges may reduce earthworm densities. Further investigations are needed to determine why earthworm density differs amongst different landscapes, particularly those with and without adjacent forest.

We also observed that epigeic species were rarely found at the levee grasslands in this study. Epigeic species live in the litter layer and feed on litter (Uchida and Kaneko 2004, Ishizuka 2015). The unstable supply of litter on levees may be a factor in their low density. Two types of litter were found on the paddy levees: grass and forest litter. Both litter types are not likely to be permitted to decay, thus becoming palatable for earthworms; litter is often removed by passing farmers and machinery. In addition, the levees are usually open and litter tends to be blown away by the wind; farmers may also sweep the litter from levees after mowing. Thus, presumably due to the unstable supply of litter, epigeic species appear to be unable to settle on the levees.

Monthly changes in earthworm densities occurred in the topsoil of the levees. The changes are likely linked to the life cycles of some species. For example, for some endogeic species of Megascolecidae, cocoons hatch from April to September; thus, juveniles and adults appear throughout the year (Ishizuka 2015). Several species found in this study may exhibit this type of life cycle, as we measured high densities of non-adult individuals in September; all stages were found throughout the study period. However, in terms of $E$. japonica, the dominant species in this study, the monthly changes in density presumably did not reflect its life cycle. For example, Nakamura (1972) showed that the life cycle of $E$. japonica is such that adults appear mainly from May to October; they peak in number in August. In contrast, we observed that adults rarely appeared in August and then disappeared from the $0-10-\mathrm{cm}$ layer in September. At least for this species, monthly changes in earthworm density could reflect movement from the topsoil to deeper layers. A previous study has demonstrated that the proportions of $E$. japonica adults and sub-adults in the 10-20-cm layer are high in August; earthworms were found mostly in the $0-10-\mathrm{cm}$ layer in other months (Nakamura 1972). More detailed investigations are necessary to better understand the mechanisms driving monthly changes in earthworm density within shallow soil layers. At the very least, such monthly changes are likely to influence the availability of food resources for earthworm feeders on paddy levees. On Sado Island, reintroduced crested ibis feed primarily on earthworms in paddy levees during the period of late July to September (Endo and Nagata 2013). In addition, they cannot dig to depths deeper than $10 \mathrm{~cm}$. Their food resources may be insufficient in July and August. Thus, to conserve the foraging habitats of the crested ibis and various other animals living in satoyama, consistent monitoring of earthworms at the levees is necessary, combined with further studies of the mechanisms underlying monthly and regional changes. 


\section{Acknowledgements}

We greatly appreciate the farmers who allowed us to collect earthworms from their paddy levees. We also thank Fujio Hyodo for his analysis of soil $\mathrm{C}$ and $\mathrm{N}$ concentrations and $\mathrm{C}: \mathrm{N}$ ratios, Yukiyoshi Kamihira and Satoshi Kaneda for their helpful comments on earthworm density in grasslands and agricultural lands and Hisashi Nagata for his valuable comments on the crested ibis. This research was supported by the Environment Research and Technology Development Fund (4-1606) of the Ministry of the Environment, Japan.

\section{References}

- $\quad$ Andren H (1992) Corvid density and nest predation in relation to forest fragmentation: $\mathrm{A}$ landscape perspective. Ecology 73 (3): 794-804. https://doi.org/10.2307/1940158

- Bansho K (2019) Ten years of the crested ibis, Nipponia nippon, reintroduction and conservation in Japan. National Parks 770: 4-7. [In Japanese].

- $\quad$ Blakemore R, Kupriyanova E, Grygier M (2010) Neotypification of Drawida hattamimizu Hatai, 1930 (Annelida, Oligochaeta, Megadrili, Moniligastridae) as a model linking mtDNA (COI) sequences to an earthworm type, with a response to the 'Can of Worms' theory of cryptic species. ZooKeys 41: 1-29. https://doi.org/10.3897/zookeys.41.374

- $\quad$ Endo C, Nagata H (2013) Seasonal changes of foraging habitats and prey species in the Japanese Crested Ibis Nipponia nippon reintroduced on Sado Island, Japan. Bird Conservation International 23 (4): 445-453. https://doi.org/10.1017/ $\underline{\text { s0959270912000457 }}$

- Harada H, Yoshimura K (2015) The ecological distribution and diversity of soil fauna. Tokai University Press, Kanagawa [In Japanese].

- Hirai T, Matsui M (2000) Feeding habits of the Japanese tree frog, Hyla japonica, in the reproductive season. Zoological Science 17: 977-982. https://doi.org/10.2108/zsj.17.977

- Hirai T, Matsui M (2001) Diet composition of the Indian rice frog, Rana limnocharis, in rice fields of central Japan. Current herpetology 20 (2): 97-103.

https://doi.org/10.5358/hsj.20.97

- Hokkaido Development (1965) Report on soil fauna for conserving grasslands. Hokkaido Development, Sapporo [In Japanese].

- Ishizuka K (2015) Academic study of earthworms. Morphology, ecology, taxonomy, and research methods of Japanese earthworms (Genus Pheretimas. lat.). Zenkoku Nouson Kyouiku Kyoukai, Tokyo [In Japanese].

- Kamihira Y (1968) On sampling areas to find the density of population in terrestrial Oligochaeta (part 2). The Review of Hakodate University 3: 65-72. [In Japanese].

- Kamihira Y (1969) Investigations of the earthworm population density, the biomass, and the pattern of spatial distribution. The Review of Hakodate University 4: 49-59.

[In Japanese].

- Kamihira Y (1973) Ecological studies on the terrestrial Oligochaeta in Hakodate, Hokkaido. Seibutsu Kyouzai 7: 43-51. [In Japanese].

- $\quad$ Kiritani K (2010) A comprehensive list of organisms associated with paddy ecosystems in Japan. Noutoshizennokenkyujo, Fukuoka [In Japanese]. 
- $\quad$ Lee KE (1985) Earthworms. Their ecology and relationships with soils and land use. Academic Press Australia, N.S.W.

- Magura T (2002) Carabids and forest edge: spatial pattern and edge effect. Forest Ecology and Management 157: 23-37. https://doi.org/10.1016/s0378-1127(00)00654-X

- Matsumura T, Uchida K, Sawada Y (2014) Conditions and conservation for biodiversity of the semi-natural grassland vegetation on rice paddy levees. Vegetation Science 31: 193-218. [In Japanese].

- Minamiya Y, Ishizuka K, Tsukamoto J (2007) Habitat preference of surface living earthworms as food for fairy pitta, a forest songbird, in warm-temperate south-western Japan. Edaphologia 81: 13-26.

- Molnár T, Magura T, Tóthmérész B, Elek Z (2001) Ground beetles (Carabidae) and edge effect in oak-hornbeam forest and grassland transects. European Journal of Soil Biology 37 (4): 297-300. https://doi.org/10.1016/s1164-5563(01)01103-7

- Nagata H (2010) Dispersal and foraging behaviors of re-introduced crested ibis Nipponia nippon in Sado Island. Environmental Research Quarterly 158: 69-74. [In Japanese].

- Nagata H, Yamagishi S (2016) Which factors affect post-release settlement of crested ibis Nipponia nippon on Sado Island, Japan? Ornithological Science 15 (2): 181-189. https://doi.org/10.2326/osj.15.181

- Nakamura Y (1967) Population density and biomass of the terrestrial earthworm in the grasslands of three different soil types near Sapporo. Japanese Journal of Applied Entomology and Zoology 11 (4): 164-168. [In Japanese].

https://doi.org/10.1303/jjaez.11.164

- Nakamura Y (1972) Studies on soil animals in grassland. II. Age distribution of Allolobophora japonica Michaelesen population in forage swards. Japanese Journal of Grassland Science 18: 172-176. [In Japanese].

- Ohara R, Ushimaru A (2015) Plant beta-diversity is enhanced around grassland-forest edges within a traditional agricultural landscape. Applied Vegetation Science 18 (3): 493-502. https://doi.org/10.1111/avsc. 12166

- Ohwaki A, Kaneko Y, Ikeda H (2015) Seasonal variability in the response of ground beetles (Coleoptera: Carabidae) to a forest edge in a heterogeneous agricultural landscape in Japan. European Journal of Entomology 112 (1): 135-144.

https://doi.org/10.14411/eje.2015.022

- $\quad$ Okuzaki Y, Tayasu I, Okuda N, Sota T (2010) Stable isotope analysis indicates trophic differences among forest floor carabids in Japan. Entomologia Experimentalis et Applicata 135 (3): 263-270. https://doi.org/10.1111/j.1570-7458.2010.00987.x

- $\quad$ Onrust J, Piersma T (2017) The hungry worm feeds the bird. Ardea 105 (2): 153-161. https://doi.org/10.5253/arde.v105i2.a4

- $\quad$ R Core Team (2017) R: A language and environment for statistical computing. R Foundation for Statistical Computing, Vienna, Austria.

- Reynolds J (1978) The earthworms of Tennessee (Oligochaeta). IV. Megascolecidae, with notes on distribution, biology and a key to the species in the state.

Megadrilogica 3: 117-12.

- $\quad$ Sklenicka P, Lhota T, Cecetka J (2002) Soil porosity along a gradient from forest edge to field. Die Bodenkultur 53: 191-197. 
- Tatara M, Doi T (1994) Comparative analyses on food habits of Japanese marten, Siberian weasel and leopard cat in the Tsushima Islands, Japan. Ecological Research 9: 99-107. https://doi.org/10.1007/BF02347247

- Uchida K, Ushimaru A (2014) Biodiversity declines due to abandonment and intensification of agricultural lands: patterns and mechanisms. Ecological Monographs 84 (4): 637-658. https://doi.org/10.1890/13-2170.1

- Uchida T, Kaneko N (2004) Life history of Megascolecidae earthworms in forest soils at Kanagawa, Japan. Edaphologia 74: 35-45. [In Japanese].

- Uematsu Y, Ushimaru A (2013) Topography- and management-mediated resource gradients maintain rare and common plant diversity around paddy terraces. Ecological Applications 23 (6): 1357-1366. https://doi.org/10.1890/12-1939.1

- Uruma H, Kobayashi R, Nishijima S, Miyashita T (2012) Effectiveness of conservationoriented agricultural practices on amphibians inhabiting Sado Island, Japan, with a consideration of spatial structure. Japanese Journal of Conservation Ecology 17: 155-164. [In Japanese].

- Ushimaru A (2012) Satokusachi. In: Suka T, Okamoto T, Ushimaru A (Eds) Grasslands and Japanese. Tsukiji Shokan, Tokyo [In Japanese].

- Yokohata Y (2005) A brief review of the biology on moles in Japan. Mammal Study 30: S25-S30. https://doi.org/10.3106/1348-6160(2005)30[S25:ABROTB]2.0.CO;2

\section{Supplementary materials}

\section{Suppl. material 1: Methods for the measurements of landscape conditions and soil properties doi}

Authors: Keiko Kishimoto-Yamada and Yukio Minamiya

Data type: methods

Download file $(65.38 \mathrm{~kb})$

Suppl. material 2: Species occurrences of levee earthworms on Sado Island. doi

Authors: Keiko Kishimoto-Yamada and Yukio Minamiya

Data type: occurrences

Download file $(61.14 \mathrm{~kb})$ 